\title{
Critical Thinking Master Student Preferred Learning Aids: An Experimental Study
}

\author{
T. Christine Gordon, Ph.D. a*, Veronika Ospina-Kammerer, Ph.D. a \\ a Saint Leo University \\ ${ }^{*}$ Corresponding author's email address:
}

\section{A R T I C L E I N F O}

Received: 30-11-2015

Accepted: 17-03-2016

Available online: 02-04-2016

\section{Keywords:}

Assessment, Chi Square Testing,

Critical Thinking,

Learning Aid Preference.

JEL Classification:

\begin{abstract}
A B S T R A C T
Case Analysis is not new in the realm of learning, use of learning aids and assessment. Critical Thinking requires product design/course, paper completion, and research/ citations in support of the student statements and specific parameters of the paper. Teaching and learning theories (inductive and deductive) and critical thinking are the benchmarks in determining the success of teaching techniques in a course. The deductive method includes a preset assessment. The "Table of Contents" structures student learning. A study, of three online Master student cohort groups, was designed to test for (no) preferences of student course aids with respect to critical thinking, learning and assessment. The Chi Square Goodness of Fit testing shows a statistically significant preference for the "Table of Contents" as a preferred learning aid.
\end{abstract}

(C) 2016 The Authors. This is an open access article under the terms of the Creative Commons Attribution License 4.0, which allows use, distribution and reproduction in any medium, provided the original work is properly cited.

DOI: http://dx.doi.org/10.18533/rss.v1i3.15

\subsection{Introduction}

This paper, a time series, presents an overview of student preferences in course aids for Case Analysis/Problem Based Learning (PBL) assessments. It looks at a variety of student aids and also references a variety of assessment instruments. The paper focuses on critical thinking and student course papers. PBL supports critical thinking in that it requires product design/course paper completion, research/citations in support of the student statements, and specific parameters of the paper. PBL requires that someone, other than the learner, is responsible for both the learning situations and management of the assessments (Thomas, 2003). Teaching and learning are directly tied to educational theories. These theories are benchmarks in determining both the success of teaching techniques and proof of student learning.

The survey findings, as a time series of cohort, online groups, are also applicable to the following learning theories:

Grow's (Grow, 1991) theory of Self Directed Development is closely matched to actual/existing situations. The student must become decisive, resourceful, investigative, critical thinkers based on assigned objectives in the course, self - directed and independent learners. As students gain the skills needed for self - direction, the teacher becomes less directive. (Grow, 1991, pp. 125 - 149).

Curriculum Design Theory: a similar progression towards self - directed learning can be applied to a course curriculum. 


\section{$2.0 \quad$ Approaches}

The learning theories are interrelated to two teaching and learning methods. The methods are inductive and deductive. In inductive the teacher exposes the learner to many topic situations. The student will learn by trial and error. This is known as the stimulus - response result in behaviorist habit forming theory. The deductive method includes a preset formula for the assessment. Rules structure student learning. The student's critical thinking becomes a guided and/or self-guided learning process. This is the constructivist pattern process in learning. (Thomas, 2003, p. 3).

A survey questionnaire was administered to three cohort groups Master of Business Administration students. A sample of 65 students were surveyed and 53 students responded.

Chi Square Goodness of Fit testing, at alpha a priori .05 results were statistically significant regarding student preferences of learning aids.

Ho: The categories of student materials/work are equally likely to aid student learning

(Students do not have a clear/significant preference of course learning aids)

Ho: $\mathrm{po}=\mathrm{p} 1=\mathrm{p} 2=\mathrm{p} 3=\mathrm{p} 4=\mathrm{p} 5$

H1: (Ha) Students do have a preference of course materials to aid their learning

Chi Square Goodness of Fit Testing Formula $=$

$$
\begin{gathered}
\mathrm{X}^{2}=\mathrm{E}(\mathrm{O}-\mathrm{E})^{2} \\
-\mathrm{E}
\end{gathered}
$$

$\mathrm{k}-1$ degrees of freedom

$\mathrm{k}=$ number of categories $/ 5-1=4 \mathrm{df}$

(This is always a right tailed test.)

\subsection{Assessment}

Course objectives generally drive the assessments in learning. Assessment is expected by the learner and it is both competitive and non-competitive tools. Criterion testing is non-competitive. Norm referenced tests compare one learner to another in past or current situational events.

PBL is closely matched to actual/existing situations. The students must be decisive, resourceful, investigative, critical thinkers based on assigned objectives, self-directed, and independent learners. They should (will) find solutions. Often the solutions are found by researching online.

Multimedia benefits enhance the student's decisive and critical thinking based on assigned objectives of selfdirected and independent learners. Evidence suggests that lectures can present barriers to learning for many students. Online multimedia materials could offer many benefits for both teachers and students. (Wald 2008).

\subsection{Catalyst to learning}

Those surveyed preferred ownership and problem solving in learning. Paper/case study assessment, to include online research, were the methods of assessments used and required solutions, selection choices, regarding situational practices/problems.

It is important to nurture these Master candidates through training activities during their program of study (Baker, 1989). The ideal student might become the ideal "professional". They would have a sense of self-worth, respect others, be loyal to their sponsor, maintain the highest of standards in their field, give care that is honest, accurate and gentle, consider the patient on the whole as body, mind, and spirit and will also, by role modeling, encourage growth of their ranks (Brown-West, 1991; Carnevale, Villet, and Holland, 1990; Fauser, 1992; McMillan \& Reed, 1994).

Educators have to address any or all of the following issues: retraining of displaced workers; content expansion; theory and methodology of instruction; increased education in licensed occupations will enhance the image and expand the arena of adult education. Required continuing education will increase development of testing and certification (Bell, 1988; Buzzell, 1986; Daggett, 1991; Dole, 1989; Gupta \& Konrad, 1992; Schroeder, 1993). 


\subsection{Students and Learning Preferences}

A survey questionnaire was administered to cohort groups Master of Business Administration students. There were 65 students surveyed and 53 responses. The study was designed to test for (no) preferences of student course aids with respect to critical thinking, learning and assessment. The aids included the text, lectures, subject handouts, specific end of course paper table of contents, and a sample (rubric) paper. The expected tally for no preference of course aids was $20 \%$ per category. The course delivery format (in this experiment) was to online only cohort groups.

Chi Square Goodness of Fit Testing suggested that a given Table of Contents/Tree flow diagram, as the course weekly paper assessment, was most preferred by more than $90 \%$ of the responders. A clear winner for student second choice of aid was a rubric paper.

\subsection{Evaluation Outcomes}

All graduate responders reported that course aids (used in the cohort online courses) were also helpful in their "follow on" courses.

These five course aids (in preferred rank order) are:

1. Preset/given paper table of contents

2. Rubric/sample report

3. Subtopic lectures

4. Student sharing/group work

5. Text book

The Chi Square results suggest there is a significant difference in student learning aid preferences and assessments at .05 percent.

\subsection{Conclusion}

The teaching and learning theories (inductive and deductive) and critical thinking are the benchmarks in determining the success of teaching techniques in a course (Thomas, 2003). The "Table of Contents"/Tree flow diagram is the hallmark of preferred learning aids for students.

This research is unique as specific learning aids were tested to include a "Table of Contents". This aid has not been considered and/or reported in the literature by other researchers. A time series approach enhances the findings. The Chi Square Goodness of Fit test results suggest there is a significant difference in student learning aid preferences and at alpha a priori .05 percent.

As a policy change, the Health Care Administration division of Saint Leo University, School of Business, will use the "Table of Contents" in most Health Care courses that have a paper due.

The next policy change will be to mandate it's use in online Health Care courses.

Future research suggests additional studies, such as e readings to replace the use of a course text book, would prove to be both interesting and valuable.

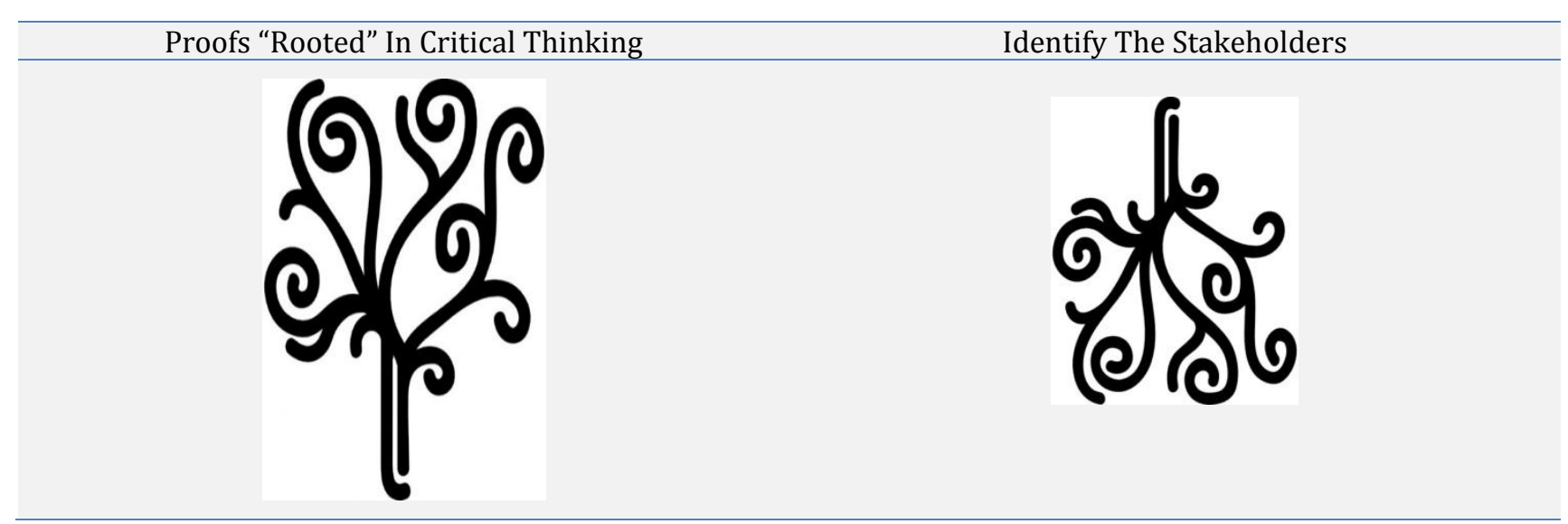




\section{References}

Akbulut, Y. (2007). Effects of multimedia annotations on incidental vocabulary and reading comprehension of advanced learners of English as a foreign language, Instructional Science, (pp. 499-517). http://dx.doi.org/10.1007/s11251-007-9016-7

Ardac, D., \& Unal, S. (2008). Does the amount of on-screen text influence student learning from a multimediabased instructional unit? Instructional Science: An International Journal of the Learning Sciences, (pp. 7588).

Bain, K., Basson, S.A., Faisman, A., Kanevsky, D. (2005). Accessibility, transcription, and access everywhere, IBM Systems Journal, (pp. 589-603). Retrieved December 12, 2005, from http://www.research.ibm.com/journal/sj/443/bain.pdf; http://dx.doi.org/10.1147/sj.443.0589

Baker, J. (Summer, 1989). The recruitment and retention of minority and disadvantaged allied health students. Journal of Allied Health, (pp. 389-401).

Bell, C.W. (October 7, 1988). Training tomorrow's workers. (Hospital Labor Shortage) (editoral). Modern Healthcare, (p. 88).

Brockett, R. G. (2002). Conceptions of self-directing learning (Book Review). Adult Education Quarterly, (pp. 155-156). http://dx.doi.org/10.1177/0741713602052002006

Brown-West, A. P. (Summer, 1991). Influences of career choice among allied health students. Journal of Allied Health, (pp. 181-189).

Buzzell, C.H. (1993). Tech prep, special needs, and the Perkins Act. Vocational Education Journal, (pp. 4-5).

Carnevale, A. P., Gaines, L. J., Villet, J., \& Holland, S. L. (1990). Training partnerships: Linking employers and providers. Alexandria, Virginia: American Society for Training and Development, Washington, D.C.: U.S. Department of Labor. Employment and Training Administration.

Chizmar, J.F., \& Walbert, M.S. (1999). Web-based learning environments guided by principles of good teaching practice. Journal of Economic Education, (pp. 248-264). http://dx.doi.org/10.2307/1183061

Chun, D. M. (2001). L2 reading on the web: Strategies for accessing information in hypermedia. Computer Assisted Language Learning, (pp. 367-403). http://dx.doi.org/10.1076/call.14.5.367.5775

Chun, D.C., Payne, J.S. (2004). What makes students click: working memory and look-up behavior. System (pp. 481-504). http://dx.doi.org/10.1016/j.system.2004.09.008

Dagget, Dr. W. R. (1991). The future of employment and implications for education.

Dole, E. (October, 1989). Preparing the work force of the future. Vocational Educational Journal, (pp. 18-20).

Fauser, J.J. (1992). Accreditation of allied health education: Assessing for educational effectiveness. The Journal of the American Medical Association, (p.1123). http://dx.doi.org/10.1001/jama.1992.03490090065016

Garrison, D.R. (2003). Self-directed learning and distance education, In M.G. Moore \& W. Anderson (eds.), Handbook of Distance Education (pp. 161-168). Mahwah, NJ: Lawrence Erlbaum.

Graff, M. (2003). Individual Differences in Sense of Classroom Community in a Blended Learning Environment. Journal of Educational Media, Vol. 28, Nos. 2-3. http://dx.doi.org/10.1080/1358165032000165635

Grow, G. (1991). Teaching learners to be self-directed: A stage approach. Adult Education Quarterly, (pp. 125149). http://dx.doi.org/10.1177/0001848191041003001

Gupta, G.C. \& Konrad, T.R. (1992). Allied health education in rural health professional shortage areas of the United States. The Journal of the American Medical Association, (pp. 268, 1127). http://dx.doi.org/10.1001/jama.1992.03490090069017

Hannafin, M.J., Hill, J.R., Oliver, K., Glazer, E., \& Sharma, P. (2003). Cognitive and learning factors in Web-based distance learning environments. In M.G. Moore, \& W.G. Anderson (Eds.), Handbook of distance education (pp. 245-260). Mahwah, NJ: Lawrence Erlbaum

Harrison, R. (1978). How to design and conduct self-directed learning experiences. Group and Organization Studies, (pp. 149-167). http://dx.doi.org/10.1177/105960117800300203

Hill, J.R., \& Hannafin, M.J. (2001). Teaching and learning in digital environments: The resurgence of resourcebased learning. Educational Technology Research and Development, (pp. 37-52). http://dx.doi.org/10.1007/BF02504914

McMillan, J. H., \& Reed, D.F. (1994). At-risk students and resiliency: Factors contributing to academic success. The Clearing House, (p. 137). http://dx.doi.org/10.1080/00098655.1994.9956043

Merriam, S.B. (2001). Andragogy and self-directed learning. New Directions for Adult and Continuing Education,(pp. 3-14). http://dx.doi.org/10.1002/ace.3

Merriam, S.B. \& Caffarella, R.S. (1999). Learning in Adulthood. San Francisco: Jossey-Bass.

Ozono, S. \& Ito, H. (2003). Logical connectives as catalysts for interactive L2 reading. System, (pp. 283-297). http://dx.doi.org/10.1016/S0346-251X(03)00025-3

Schroder, C.C. (1993). New students - new learning styles. Change, (p. 21). http://dx.doi.org/10.1080/00091383.1993.9939900

Song, L. (2005). Adult learners' self-directed learning in online environments: Process, personal attribute, and context. Unpublished Dissertation, The University of Georgia, Athens, GA. 
Song, L., Singleton, E.S., Hill, J.R., \& Koh, M.H. (2004). Improving online learning: Student perceptions of useful and challenging characteristics. Internet \& Higher Education, (pp. 59-70). http://dx.doi.org/10.1016/j.iheduc.2003.11.003

Thomas, M., (2003) Assessment and Learner Performance in Problem Based Learning (PBL). Number 1. Vol 1. Singapore: Temaskey Polytechnic

Tozcu, A. \& Coady, J. (2004). Successful learning of frequent vocabulary through CALL also benefits reading comprehension and speed. Computer assisted language learning, (pp. 473-495). http://dx.doi.org/10.1080/0958822042000319674

Wald, M., (2008) Learning Through Multimedia: Automatic Speech Recognition Enhancing Accessibility and Interaction. Journal of Educational Multimedia and Hypermedia, (pp. 215-233). 